(C)2013 Science Publication

doi:10.3844/ajeassp.2013.252.262 Published Online 6 (3) 2013 (http://www.thescipub.com/ajeas.toc)

\title{
Photocatalytic Decolourization of Textile Effluent Containing Reactive Red 120 Dye With UV/TiO
}

\author{
Rishi Ananthashankar and Abdel Ghaly
}

Department of Process Engineering, Faculty of Engineering, Dalhousie University, Halifax, Nova Scotia, Canada

Received 2013-06-28; Revised 2013-07-22; Accepted 2013-07-26

\begin{abstract}
The efficiency of degradation of an aqueous solution of reactive red 120 dye using Advanced Oxidation Process (AOP) was evaluated. A low pressure UV lamp and a combination of $\mathrm{UV} / \mathrm{TiO}{ }_{2}$ were tested using ten different dye concentrations $(50-500 \mathrm{mg} / \mathrm{L})$ at several retention times $(5.2-60 \mathrm{~min})$ a $\mathrm{pH}$ of 10.5 . The effect of acidic $\mathrm{pH}(\mathrm{pH}=3)$ on dye removal efficiency and the Chemical Oxygen Demand (COD) of the treated effluents were also investigated. When the alkaline $(\mathrm{pH}=10.5)$ reactive red 120 dye solutions were treated using a low pressure (380 nm intensity) UV lamp, a maximum degradation efficiency of $27.01 \%$ was obtained for the least concentrated dye $(50 \mathrm{mg} / \mathrm{L})$ solution and only a degradation efficiency of $0.33 \%$ was obtained for the most concentrated $(500 \mathrm{mg} / \mathrm{L})$ dye solution. When the alkaline $(\mathrm{pH}=10.5)$ reactive red 120 solutions were exposed to a combination of $\mathrm{UV} / \mathrm{TiO}_{2}$, a maximum degradation efficiency of $46.70 \%$ was obtained for the lease concentrated $(50 \mathrm{mg} / \mathrm{L})$ dye solution after $60 \mathrm{~min}$ and only a degradation efficiency of $2.84 \%$ was obtained for the most concentrated $(500 \mathrm{mg} / \mathrm{L})$ dye solution after $60 \mathrm{~min}$. When the $\mathrm{pH}$ of the reactive red 120 dye solution was reduced to 3, a degradation efficiency of $56.45 \%$ was obtained for the least concentrated $(50 \mathrm{mg} / \mathrm{L})$ dye solution at $60 \mathrm{~min}$ and a degradation efficiency of $14.94 \%$ was obtained for the most concentrated $(500 \mathrm{mg} / \mathrm{L})$ dye solution at $60 \mathrm{~min}$. However, the increase in degradation efficiency obtained in this study does not justify the cost of chemicals added to adjust the $\mathrm{pH}$ to 3 before treatment and then to 7 before final disposal. Also, the addition of chemicals (to adjust the $\mathrm{pH}$ ) increases the COD of the dye solution thereby necessitating a further costly treatment.
\end{abstract}

Keywords: Textiles, Wastewaters, Dyes, Reactive red 120, UV, $\mathrm{TiO}_{2}, \mathrm{UV} / \mathrm{TiO}_{2}$, Exposure, Time

\section{INTRODUCTION}

Textile industries are often considered a pillar in the economic growth of developing (and developed) countries (Chen et al., 2007). They are the backbone of employment in poor countries by providing job with no specialised skills (Keane and Velde, 2008). However, Textile industries are known to utilize huge amounts of water and chemicals in the textile production processes. Kant (2012) reported that a normal sized textile industry, which produces about $8000 \mathrm{~kg}$ of textiles per day, utilizes 1.6 million liters of water and $815.68-924.06 \mathrm{~kg}$ of chemicals per day (about $\left.0.51-0.58 \mathrm{~kg} / \mathrm{m}^{3}\right)$.
Textile fibres undergo various processes including sizing, desizing, scouring, bleaching, mercerizing, dyeing and printing. Various treatment processes are carried out depending on the type of textile fibres (cellulose, protein or synthetic fibre) processed. Numerous amounts of chemicals such as dyes, fixing agents, leveling agents and $\mathrm{pH}$ regulators are used during these processes (Ntuli et al., 2009). About 70,000 tonnes of pigments and dyes are used by textile industries annually (Azbar et al., 2004). There is always a portion of dyes that is not fixed to the fabrics during the textile dyeing process and is washed out during the finishing process with the textile effluent (Dyes and Pigments, 2010). Because these effluents are rich in dyes and chemicals (COD, dissolved solids, BOD and heavy

Corresponding Author: Abdel Ghaly, Department of Process Engineering, Faculty of Engineering, Dalhousie University, Halifax, Nova Scotia, Canada Email: Abdel.Ghaly@dal.ca 
metals), they cause major environmental and health concerns (Meric et al., 2004; Eswaramoorthi et al., 2008). Prolonged exposure to textile effluents causes dermatitis, severe irritation, ulceration and even cancer (Nese et al., 2007; Jain et al., 2003).

Textile effluents undergo primary, secondary and tertiary treatments before getting disposed of into the environment. Primary treatments such as screening, sedimentation and coagulation are helpful in removing the suspended solids from the effluent (EPA, 2003). Secondary treatments like aerated lagoons, trickling filters and activated sludge systems are used for the removal of $\mathrm{BOD}, \mathrm{COD}$ and organic substances in the effluent (Das, 2000; Lafond, 2008; Tilley et al., 2008). Tertiary treatment processes including reverse osmosis and electrodialysis are used to separate the effluents from dissolved metal ions or dissolved salts (Das, 2000; Babu et al., 2007). However, these treatment methods are not effective against certain textile dyes. Some of the dye stuff have complex structures which are nearly impossible to be broken down by simple treatment processes (Ghoreishi and Haghighi, 2003).

Advanced Oxidation Processes (AOP) is a newly developed field which makes use of $\mathrm{OH}^{\circ}$ radicals to destroy chemical components that are hard to be oxidised (Alfons and Soo-Myung, 2003; Kdasi et al., 2004; Mahmoud et al., 2007). The oxidants used to generate $\mathrm{OH}^{\circ}$ radicals individually or in a combination include $\mathrm{H}_{2} \mathrm{O}_{2}, \mathrm{UV}, \mathrm{O}_{3}, \mathrm{TiO}_{2}, \mathrm{Fe}^{2+}$, electron beam irradiation and ultra sound (Kdasi et al., 2004). $\mathrm{OH}^{\circ}$ radicals are found to have an oxidation potential of 2.33 $\mathrm{V}$ and are capable of destroying components that are hard to be oxidised. (Stasinakis, 2008; Gogate and Pandit, 2004; Eswaramoorthi et al., 2008). The advantages of advanced oxidation technologies over other tertiary treatments are: they are fast, do not produce secondary components and do not produce sludge and as such there is no sludge disposal problem (Azbar et al., 2004).

\section{OBJECTIVE}

The main aim of the study was to investigate the degradation of Reactive Red 120 (HE3B) dye solutions of varying concentration $(50-500 \mathrm{mg} / \mathrm{L})$ by Advanced Oxidation Processes. The specific objectives were: (a) to study the effect of UV on the degradation of reactive red 120 , (b) to study the effect of combined UV and $\mathrm{TiO}_{2}$ treatment on the degradation of reactive red 120 dye and (c) study the effect of acidifying the dye solution to $\mathrm{pH} 3$ on the degradation efficiency and (d) determine the chemical oxygen demand removal efficiency of the best treatment.

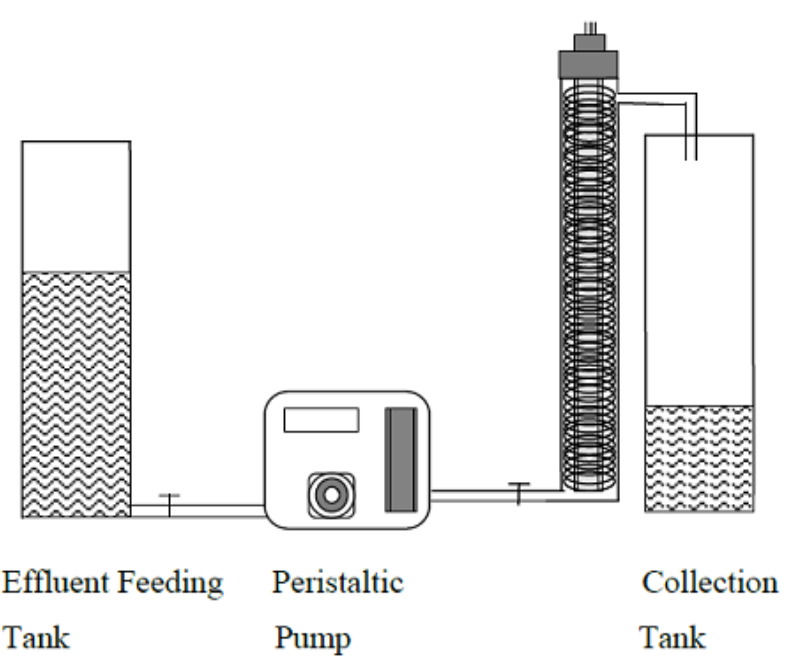

Fig. 1. The photooxidation system

\section{MATERIALS AND METHODS}

\subsection{Experimental Apparatus}

The experiments were carried out using a custom built photooxidation system (Fig. 1). The system consisted of a reactive red 120 dye feeding tank, a peristaltic pump, a photoreactor and an effluent collection tank.

The photoreactor (Fig. 2) has an outer and the inner diameters of 61 and $55 \mathrm{~mm}$, respectively. A low pressure mercury lamp (Model UV-3020, Trojan, London, Ontario, Canada), which emits UV light at $380 \mathrm{~nm}$ and is enclosed in a $21 \mathrm{~mm}$ diameter quartz tube, was used in the photoreactor. The $3 \mathrm{~mm}$ stainless steel chamber provides a gap of $17 \mathrm{~mm}$ (distance between the quartz sleeve and the inner surface of the reactor casing). A coil (448 $\mathrm{mm}$ long and $0.85 \mathrm{~mm}$ thick) made out of stainless steel (Fig. 3) with an internal diameter of $21 \mathrm{~mm}$ and a pitch of $20 \mathrm{~mm}$ was used to create mixing through the spiral motion of the liquid. The working volume of the reactor was $840 \mathrm{~mL}$.

A $12 \mathrm{~L}$ dye feeding tank was made of a $20 \mathrm{~cm}$ diameter Poly Vinyl Chloride (PVC) container. The PVC container has a detachable top and a fixed bottom made of $4 \mathrm{~mm}$ thick Poly Methyl Methacrylate (PMMA or Plexiglas ${ }^{\mathrm{TM}}$ ) plates. The detachable top has a $4 \mathrm{~mm}$ diameter opening to equalize the pressure caused by pumping out the dye from the container by allowing the air flow into the container. A $4 \mathrm{~mm}$ outlet port is located in the lower end of the feeding tank and connected to the feeding pump. 


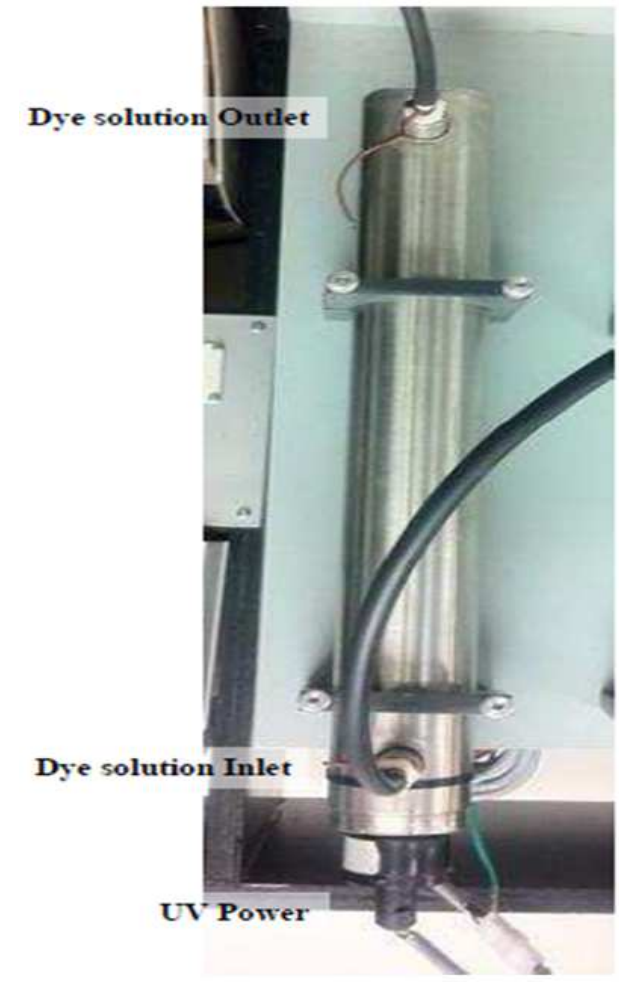

Fig. 2. Photo reactor

Masterflex precision tubing (06409-14 TYGON) was used along with a peristaltic pump (Digi-Staltic, Masterflex Model No: 7523-60, Head Model 77200-50. Barnant Company, Division of Cole Parmer Instrument.Co., Barrington, IL) to control the flow (at the required flowrate) of dye solution into the photoreactor. The pump was connected to the feeding tanks and the photoreactor using tygon tubing.

The treated effluent was collected in another $20 \mathrm{~mm}$ diameter PVC container with a working volume of $12 \mathrm{~L}$.

The PVC container had a detachable top and a fixed bottom made of $4 \mathrm{~mm}$ thick Poly Methyl Methacrylate (PMMA or Plexiglas ${ }^{\mathrm{TM}}$ ).

\subsection{Chemicals}

The chemicals used in this study were reactive red 120 dye, tetrabuthylorthotitanate $\left(\mathrm{Ti}(\mathrm{OBu})_{4}\right)$, diethanolamine $\left(\mathrm{NH}\left(\mathrm{C}_{2} \mathrm{H}_{4} \mathrm{OH}\right)_{2}\right)$, anhydrous ethyl alcohol, sodium hydroxide $(\mathrm{NaOH})$ and hydrochloric acid $(\mathrm{HCl})$. The reactive red 120 dye was obtained from Sigma Aldrich (R0378-50G, CAS\# 61951-82-4, Sigma-Aldrich Inc., St-Louis, MO, USA). Tetrabuthylorthotitanate (Titanium (IV) n-butoxide) was obtained from Fisher Scientific (Ca \# AC223190010 Fisher scientific, Montreal, Quebec, Canada). The properties of reactive red 120 are shown in Table $\mathbf{1}$.

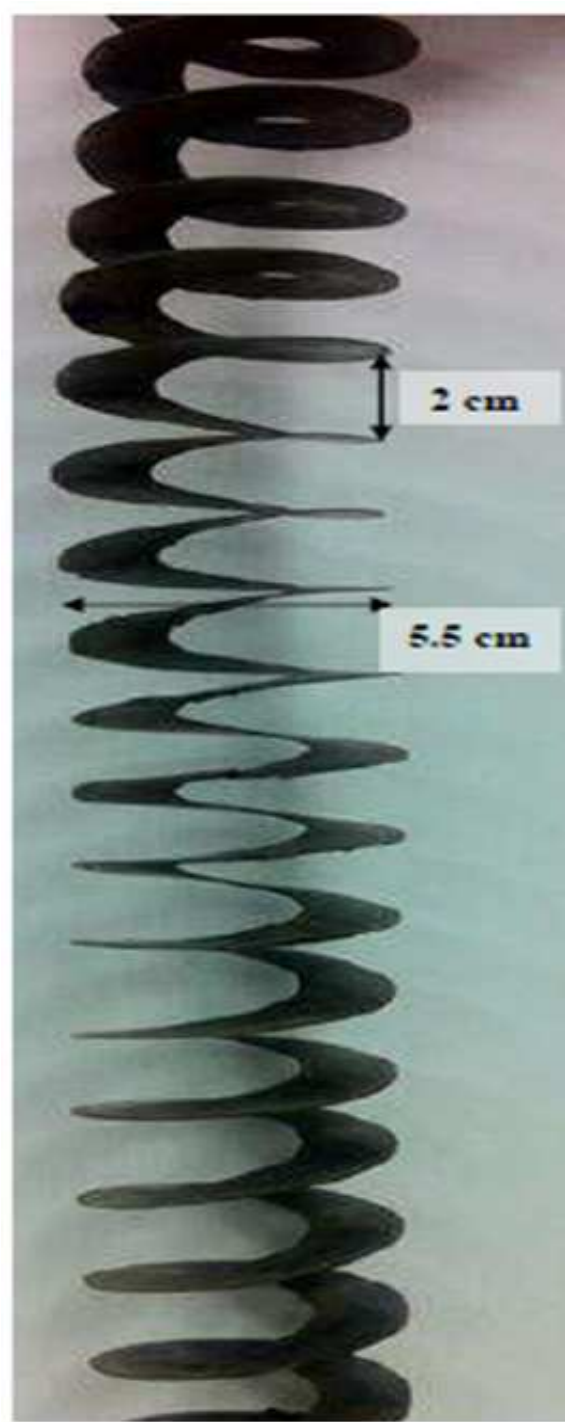

Fig. 3. Stainless steel coil

\subsection{Dye Preparation}

Ten dye concentrations in the range of $50-500 \mathrm{mg} / \mathrm{L}$ of the Reactive red 120 dye were prepared. The desired amounts of the dye to be dissolved in $12 \mathrm{~L}$ of water were weighed using a digital balance (Model No: PI 314, Denver Instruments, Bohemia, New York, USA). The solutions were mixed using a magnetic stirrer (Model No: 120S, Fisher Scientific, Ottawa, Ontario, Canada) to ensure that the dye was dissolved completely. The resulting dye solutions had a neutral $\mathrm{pH}(\mathrm{pH} 7)$. Therefore, the $\mathrm{pH}$ of the dye solutions was adjusted to 10.5 which is within the $\mathrm{pH}$ range of the textile effluent (10-11) by adding the required amount of $\mathrm{NaOH}$. $\mathrm{A} \mathrm{pH}$ meter (UB-10 Denver Instruments, Bohemia, New York, USA) was used to measure the $\mathrm{pH}$. 


\section{4. $\mathrm{TiO}_{2}$ Preparation}

$\mathrm{TiO}_{2}$ was coated on the coil using the procedure described by Verma and Ghaly (2008). $17.2 \mathrm{~mL}$ of Tetrabuthylorthotitanate and $4.8 \mathrm{ml}$ of diethanolamine were dissolved in $67.3 \mathrm{ml}$ of anhydrous ethyl alcohol and mixed vigorously for 2 hour. During mixing, $2.7 \mathrm{ml}$ of water and $10 \mathrm{ml}$ of ethanol were mixed together and added to the solution drop wise within 2 hours of mixing. The resulting solution was left to stand for 2 hours in order for the hydrolysis to take place. The stainless steel coil was coated with $\mathrm{TiO}_{2}$ by immersing the coils into the solution and letting it stand for $15 \mathrm{~min}$. The coil was withdrawn at a rate of $6 \mathrm{~mm} / \mathrm{sec}$. The resulting $\mathrm{TiO}_{2}$ coated coil was calcinated in a furnace (186 A, Fisher Scientific, Montreal, Quebec, Canada) at $100^{\circ} \mathrm{C}$ for an hour and then at $900^{\circ} \mathrm{C}$ for 2 hours. The resulting coil was fitted into the UV reactor.

\subsection{Experimental Procedure}

Experiments were carried out to investigate the degradation efficiency of the photooxidants (UV and $\mathrm{UV} / \mathrm{TiO}_{2}$ ). Ten different concentrations of the dye solution $(50,100,150,200,250,300,350,400,450,500$ $\mathrm{mg} / \mathrm{L}$ ) were tested under 12 different retention times $(5.25,10,15,20,25.45,30,35,40,46.66,49.41,56$ and $60 \mathrm{~min})$. The retention time of dye solution inside the photoreactor was achieved by controlling the flow rate of the peristaltic pump (Table 2). The flow rate was calculated using the following formula:

Flow Rate $=\frac{\text { Reactor Volume }}{\text { Retention Time }}$

\subsubsection{UV Treatment of Alkaline Dye Solutions}

The first set of experiments was carried out using UV alone. The alkaline $(\mathrm{pH}=10.5)$ least concentrated dye solution $(50 \mathrm{mg} / \mathrm{L})$ was placed in the feeding tank. The optical density (OD) of the initial dye solutions was determined. Then, the peristaltic pump was turned on and dye solution was fed into the photoreactor at the lowest retention time of $5.2 \mathrm{~min}$. Samples were collected from the effluent after reaching steady state for OD determination. The same procedure was repeated with all flow rates. The next concentrated alkaline ( $\mathrm{pH}$ of 10.5$)$ dye solution $(100 \mathrm{mg} / \mathrm{L})$ was placed in feeding tank and same procedure was followed with all flow rates. The entire process was repeated with the remaining alkaline dye solutions.
Table 1. Properties of reactive dye 120 (Red HE3B) (Vinitnantharat et al., 2003)

\begin{tabular}{lc}
\hline Properties & Value \\
\hline Chemical formula & $\mathrm{C}_{44} \mathrm{H}_{24} \mathrm{Cl}_{12} \mathrm{~N}_{14} \mathrm{Na}_{6} \mathrm{O}_{20} \mathrm{~S}_{6}$ \\
Molecular weight & 1338.09 \\
Molar Mass & 1470 \\
Charge & Negative \\
Functional group & Diazo \\
Colour \\
$\lambda$ max (nm) \\
Structure
\end{tabular}

Table 2. Flow rate and the corresponding retention time.

\begin{tabular}{cc}
\hline $\begin{array}{c}\text { Flow rate } \\
(\mathrm{ml} / \mathrm{min})\end{array}$ & $\begin{array}{c}\text { Retention Time } \\
(\mathrm{min})\end{array}$ \\
\hline 160 & 05.25 \\
84 & 10.00 \\
56 & 15.00 \\
42 & 20.00 \\
33 & 25.45 \\
28 & 30.00 \\
24 & 35.00 \\
21 & 40.00 \\
18 & 46.66 \\
17 & 49.41 \\
15 & 56.00 \\
14 & 60.00 \\
\hline
\end{tabular}

\subsection{2. $\mathrm{UV} / \mathrm{TiO}_{2}$ Treatment of Alkaline Dye Solutions}

The second set of experiments was carried out using $\mathrm{UV} / \mathrm{TiO}_{2}$. The alkaline $(\mathrm{pH}=10.5)$ least concentrated dye solution $(50 \mathrm{mg} / \mathrm{L})$ was placed in the feeding tank. The OD and COD of the initial dye solution were determined. Then, the peristaltic pump was turned on and dye solution was fed into the photoreactor at the retention time of $5.2 \mathrm{~min}$. Samples were collected from the effluent after reaching steady state for OD and COD all flow rates and the remaining alkaline $(\mathrm{pH}$ of 10.5) dye solutions $(100-500 \mathrm{mg} / \mathrm{L})$.

\subsubsection{UV/TiO ${ }_{2}$ Treatment of Acid Dye Solutions}

The third set of experiments was carried out using $\mathrm{UV} / \mathrm{TiO}_{2}$ with acidic dye solutions $(\mathrm{pH}=3)$. The $\mathrm{pH}$ of the dye solution was adjusted to 3 using $\mathrm{HCl}$. The acidic $(\mathrm{pH}=3)$ least concentrated dye solution (50 $\mathrm{mg} / \mathrm{L}$ ) was placed in the feeding tank. The OD and COD of the initial dye solution were determined. The 
peristaltic pump was turned on and the dye solution was fed into the reactor at a retention time of $5.2 \mathrm{~min}$. Samples were collected from the effluent after reaching steady state for OD and COD determinations. The same procedure was repeated using the flow rate of $60 \mathrm{~min}$. The procedure was also repeated with the acidic $(\mathrm{pH}=$ 3) most concentrated dye solution $(500 \mathrm{mg} / \mathrm{L})$ at 5.2 and 60 min retention times.

\subsection{Experimental Analysis}

The Chemical Oxygen Demand of the samples was determined according to the procedure described by APHA (1980). The optical density was determined using a spectrophotometer (DR/2500 Illuminator Model, HACH Company, Love land, Colorado, U.S.A) at 535 nm. A dye standard curve was prepared by taking samples from the ten dye concentrations $(50,100,150$, $200,250,300,350,400,450$ and $500 \mathrm{mg} / \mathrm{L}$ ) for optical density measurement. The OD values were plotted against the dye concentrations as shown in Fig. 4. The standard curve was used to determine the concentration of the treated solution.

\section{RESULTS}

\subsection{UV Treatment of Alkaline Dye Solutions}

The dye degradation efficiencies for different alkaline dye concentrations as a result of exposure to UV alone are shown in Fig. 5. Increasing the dye concentration and/or reducing the exposure time reduced the dye removal efficiency. When the least concentrated dye solution $(50 \mathrm{mg} / \mathrm{L})$ was treated with UV alone, only $27.1 \%$ of the dye was removed using the longest retention time of $60 \mathrm{~min}$ while only $1.14 \%$ of the dye was removed using the shortest retention time of 5.2 min. Also, $0.33 \%$ of the most concentrated dye solution $(500 \mathrm{mg} / \mathrm{L})$ was removed using the longest retention time of $60 \mathrm{~min}$ and no reduction was observed at retention times less than $60 \mathrm{~min}$.

\subsection{UV/TiO 2 Treatment of Alkaline Dye Solutions}

The dye degradation efficiencies for different alkaline dye concentrations as a result of exposure to $\mathrm{UV} / \mathrm{TiO}_{2}$ are shown in Fig. 6. A removal efficiency of $46.70 \%$ was observed for the least concentrated dye solution $(50 \mathrm{mg} / \mathrm{L})$ using the longest retention time of 60 min while only $1.64 \%$ removal efficiency was achieved using the shortest retention time of $5.2 \mathrm{~min}$.

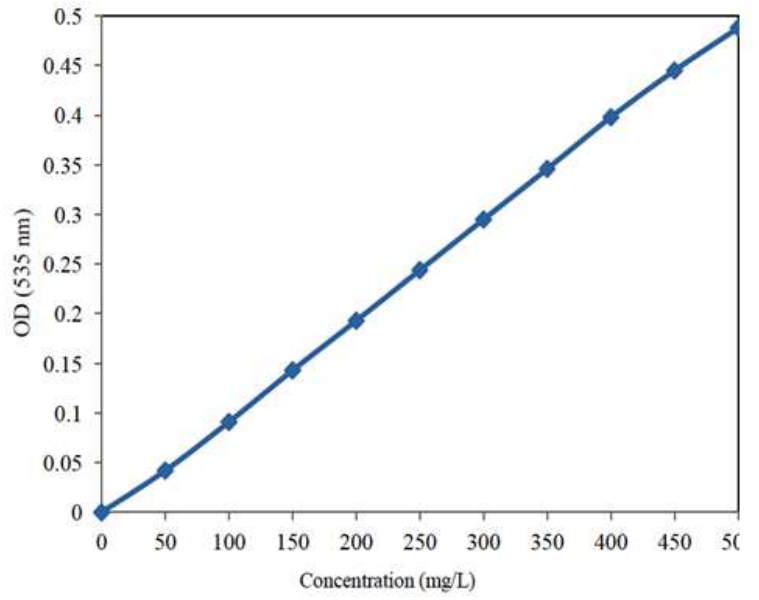

Fig. 4. Reactive 120.dye standard curve

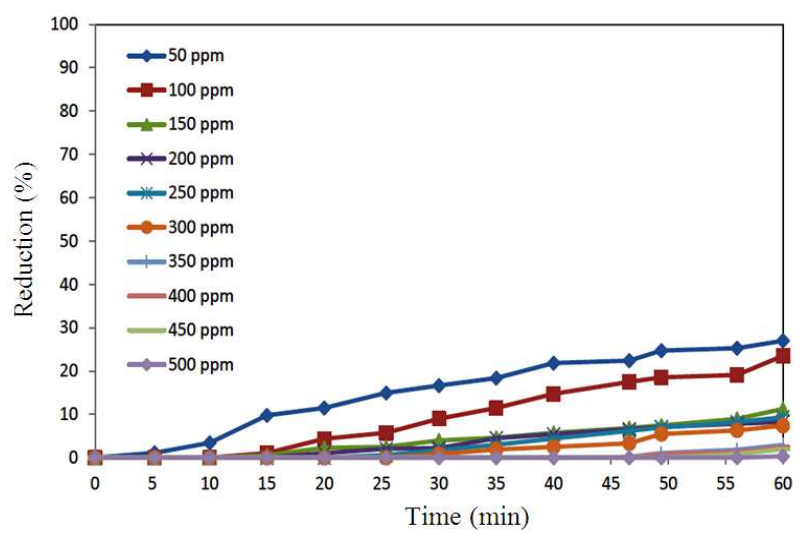

Fig. 5. Reactive 120.dye standard curve

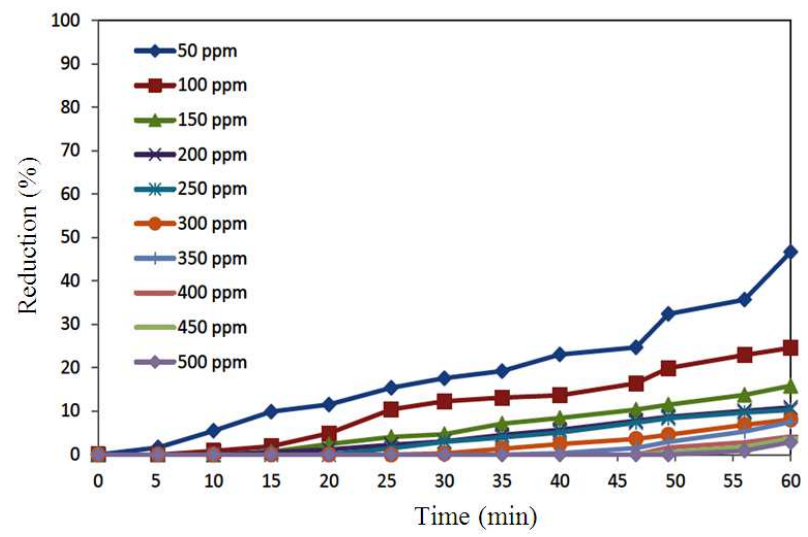

Fig. 6. Degradation efficiency of reactive red 120 dye when treated with $\mathrm{UV} / \mathrm{TiO}_{2}$

When the most concentrated dye solution $(500 \mathrm{mg} / \mathrm{L})$ was exposed to $\mathrm{UV} / \mathrm{TiO}_{2}$, only $2.84 \%$ of the dye was observed using the longest retention time of $60 \mathrm{~min}$ and 
no reduction was observed when the shortest retention time of 5.2 min was used.

\section{3. $\mathrm{UV} / \mathrm{TiO}_{2}$ Treatment of Acidic Dye Solutions}

Several researchers reported increased degradation efficiencies of textile effluent when the $\mathrm{pH}$ of the treated dye solution was decreased to 3 . In this study, the least concentrated $(50 \mathrm{mg} / \mathrm{L})$ and the most concentrated $(500$ $\mathrm{mg} / \mathrm{L}$ ) dye solutions were treated with $\mathrm{UV} / \mathrm{TiO}_{2}$ after adjusting the $\mathrm{pH}$ to 3 . The results are as shown in Table 3. A degradation efficiency of $86.45 \%$ was achieved when the acid dye $(\mathrm{pH}=3)$ of $50 \mathrm{mg} / \mathrm{L}$ concentration was exposed to $\mathrm{UV} / \mathrm{TiO}_{2}$ for $60 \mathrm{~min}$ compared to a degradation efficiency of $46.70 \%$ under the alkaline $\mathrm{pH}$ of 10.5 . Also, a degradation efficiency of $14.94 \%$ was achieved with the most concentrated $(500 \mathrm{mg} / \mathrm{L})$ acidic dye solution $(\mathrm{pH}=3)$ after being exposed to $\mathrm{UV} / \mathrm{TiO}_{2}$ for $60 \mathrm{~min}$, compared to a degradation efficiency of $2.84 \%$ under alkaline $\mathrm{pH}$ of 10.5 .

\subsection{Chemical Oxygen Demand}

Since the UV/ $\mathrm{TiO}_{2}$ treatment was more efficient than UV alone for all dye concentrations, the COD analysis was conducted on the alkaline and acidic dye solution samples obtained after treatments with $\mathrm{UV} / \mathrm{TiO}_{2}$.

The results are as shown in Table 4. COD removal efficiencies of $10.42 \%$ and $83.43 \%$ were achieved for the acidic $(\mathrm{pH}=3)$ least concentrated $(50 \mathrm{mg} / \mathrm{L})$ dye solution when exposed to $\mathrm{UV} / \mathrm{TiO}_{2}$ for 5.2 and $60 \mathrm{~min}$ compared to a COD removal efficiencies of $5.25 \%$ and $41.88 \%$ under the alkaline $\mathrm{pH}$ of 10.5 , respectively. When the acidic $(\mathrm{pH}=3)$ most concentrated $(500 \mathrm{mg} / \mathrm{L})$ dye solutions were exposed to $\mathrm{UV} / \mathrm{TiO}_{2}$ for 5.2 and $60 \mathrm{~min}$, COD removal efficiencies of 3.92 and $20.82 \%$ were achieved compared to COD removal efficiencies of 2.57 and $7.67 \%$ under the alkaline $\mathrm{pH}$ of 10.5 , respectively.

\section{DISCUSSION}

\subsection{UV Treatment}

The decomposition of textile effluent as a result of exposure to UV could be explained by the following reactions (SET, 2012; EPA US, 2012):

$\begin{array}{lll}\mathrm{O}_{2} & \stackrel{h v(\mathrm{UV})}{\longrightarrow} \mathrm{O}^{\circ}+\mathrm{O}^{\circ} \\ \mathrm{O}^{\circ}+\mathrm{O}_{2} & \stackrel{h v(\mathrm{UV})}{\longrightarrow} \mathrm{O}_{3} \\ \mathrm{O}_{3}+\mathrm{H}_{2} \mathrm{O} & \stackrel{h v(\mathrm{UV})}{\longrightarrow} & \mathrm{O}_{2}+\mathrm{H}_{2} \mathrm{O}_{2} \\ 2 \mathrm{O}_{3}+\mathrm{H}_{2} \mathrm{O}_{2} & \stackrel{h v(\mathrm{UV})}{\longrightarrow} & 2 \mathrm{OH}^{\circ}+3 \mathrm{O}_{2} \\ \mathrm{OH}^{\circ}+\text { Organics } & \longrightarrow & \text { End Product }\end{array}$

Table 3. Degradation efficiency of the reactive red 120 dye treated with $\mathrm{UV} / \mathrm{TiO}_{2}$ at various $\mathrm{pH}$ for 5.2 and $60 \mathrm{~min}$ as measured by optical density

\begin{tabular}{lccc}
\hline $\begin{array}{l}\text { Concentration } \\
(\mathrm{mg} / \mathrm{L})\end{array}$ & $\mathrm{pH}$ & $\begin{array}{c}\text { Retention } \\
\text { Time } \\
(\mathrm{min})\end{array}$ & $\begin{array}{c}\text { Degradation } \\
(\%)\end{array}$ \\
\hline 50 & -3.0 & 5.2 & 3.97 \\
& 10.5 & 60.0 & 86.45 \\
& & 5.2 & 1.64 \\
& 60.0 & 46.70 \\
\hline 500 & -3.0 & 5.2 & 0.00 \\
& 10.5 & 60.0 & 14.94 \\
& & 5.2 & 0.00 \\
& & 60.0 & 2.84 \\
\hline
\end{tabular}

Table 4. Chemical oxygen demand of reactive red 120 dye treated with $\mathrm{UV} / \mathrm{TiO}_{2}$ at varying $\mathrm{pH}$ and retention times

\begin{tabular}{lcccc}
\hline $\begin{array}{l}\text { Concentra- } \\
\text { tion } \\
(\mathrm{mg} / \mathrm{L})\end{array}$ & $\mathrm{pH}$ & $\begin{array}{c}\text { Reten- } \\
\text { tion } \\
\text { Time } \\
(\mathrm{min})\end{array}$ & $\begin{array}{c}\text { Final } \\
\mathrm{COD} \\
(\mathrm{mg} / \mathrm{L})\end{array}$ & $\begin{array}{c}\text { Degra- } \\
\text { dation } \\
(\mathrm{mg} / \mathrm{L})\end{array}$ \\
\hline & 3.0 & 60.0 & 7.95 & 83.43 \\
& & 5.2 & 45.00 & 6.25 \\
50 & 10.5 & 60.0 & 27.90 & 41.88 \\
\hline & & 5.2 & 462.80 & 3.98 \\
& 3.0 & 60.0 & 381.64 & 20.82 \\
500 & 10.5 & 6.2 & 469.60 & 2.57 \\
& & 60.0 & 445.00 & 7.67 \\
\hline
\end{tabular}

Initial COD of $50 \mathrm{mg} / \mathrm{L}$ dye concentration $=48 \mathrm{mg} / \mathrm{L}$

Initial COD of $500 \mathrm{mg} / \mathrm{L}$ dye concentration $=482 \mathrm{mg} / \mathrm{L}$

Equation 2 shows the production of atomic oxygen radicals as a result of exposure to UV. The oxygen radical $\left(\mathrm{O}^{\circ}\right)$ in turn reacts with other oxygen molecules resulting in the production of ozone $\left(\mathrm{O}_{3}\right)$ as shown in Equation 3. Equation 4 shows the reaction between ozone and water which results in the production of hydrogen peroxide $\left(\mathrm{H}_{2} \mathrm{O}_{2}\right)$. Also, ozone interacts with hydrogen peroxide to form hydroxyl radicals $\left(\mathrm{OH}^{\circ}\right)$ as shown in Equation 5. Finally, the produced hydroxyl radicals interact with the dye molecules causing the destruction of the dye (Equation 6).

In this study, the maximum degradations achieved when the alkaline $(\mathrm{pH}=10.5)$ least concentrated $(50$ $\mathrm{mg} / \mathrm{L}$ ) and most concentrated $(500 \mathrm{mg} / \mathrm{L})$ dye solutions were exposed to UV for $60 \mathrm{~min}$ were 27.01 and $0.33 \%$, respectively. The results showed that as the dye concentration increased the dye removal efficiency decreased and/or the required retention time increased. No reduction in the dye concentration was witnessed when the most concentrated alkaline $(\mathrm{pH}=10.5)$ dye solution $(500 \mathrm{mg} / \mathrm{L})$ was exposed to the UV for 56 minutes or less. This very low removal efficiency was due to the low quantity of hydroxyl radicals produced and/or 
the very short life span of ozone and hydrogen peroxide produced as reported by Kesselman et al. (1996).

Several researchers indicated that the use of UV alone as photooxidant was not very effective in destroying textile dyes. Galindo and Kalt (1999) stated that the disappearance of dye molecules when used with $\mathrm{UV}$ in the absence of other oxidants was negligible. Ince and Gonenc (1997) treated an azo dye solution having a concentration of $40 \mathrm{mg} / \mathrm{L}$ with $U V$ alone in a photoreactor and observed no significant decomposition of the dye. Ozkan et al. (2004) tested the effects of UV on the degradation of azo dyes and noted that when UV was used alone it did not give any colour reduction at a $\mathrm{pH}$ in the range of 7-11. Georgiou et al. (2002) observed no colour reduction when remazol black B dye solution was treated with UV alone. Verma and Ghaly (2008) stated that degradation of textile dyes with UV was not found effective unless it was accompanied with other oxidants/photocatalysts. However, in this study, upto $27 \%$ removal efficiency of alkaline dye with low concentration $(50 \mathrm{mg} / \mathrm{L})$ was achieved with UV alone when the 60 min retention time was used. Thus, it may be possible to achieve higher removal efficiencies with UV alone using longer retention times.

\section{2. $\mathrm{UV} / \mathrm{TiO}_{2}$ Treatment}

Titanium oxide is a naturally occurring compound with oxidizing property. Tang and An (1995) and Tang et al. (2010) proposed the following mechanism for the degradation of textile dyes with $\mathrm{TiO}_{2}$ in the presence of $\mathrm{UV}$ :

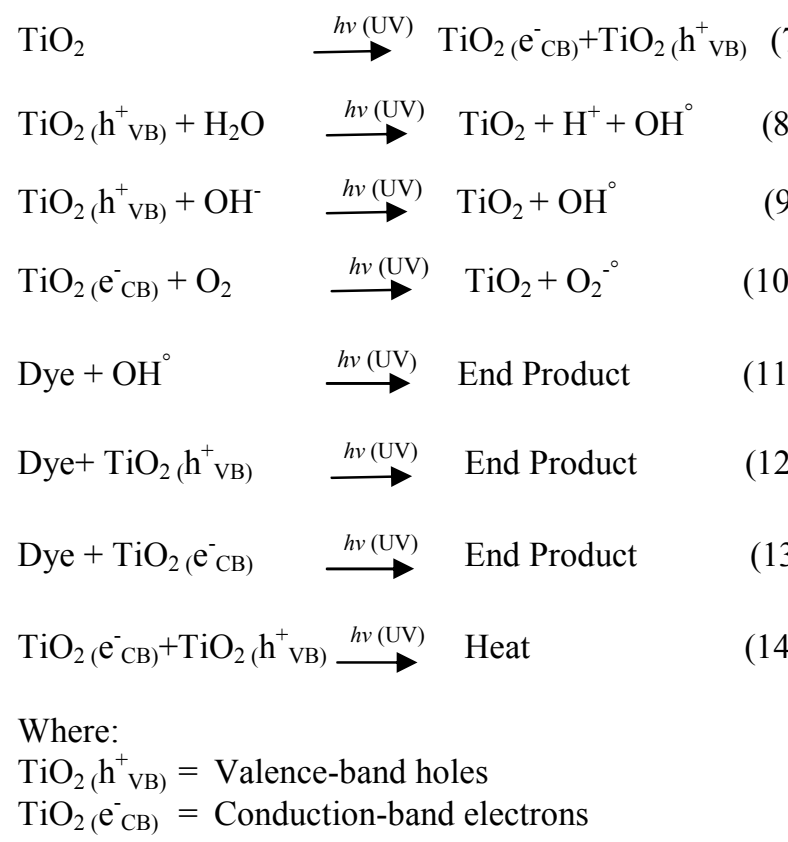

Upon irradiation by UV, the electrons on the surface of the semiconductor $\left(\mathrm{TiO}_{2}\right)$ becomes excited forming positive valance band holes $\left(\mathrm{TiO}_{2}\left(\mathrm{~h}_{\mathrm{VB})}^{+}\right)\right.$and conduction band electrons $\left(\mathrm{TiO}_{2}\left(\mathrm{e}_{\mathrm{CB}}^{-}\right)\right.$as shown in Equation 7. The valance band holes are good oxidizers and have the potential to oxidise water and $\mathrm{OH}^{-}$into $\mathrm{OH}^{\circ}$ radicals as shown in Equations 8 and 9. The conduction band electrons $\left(\mathrm{TiO}_{2}\left(\mathrm{e}_{\mathrm{CB}}^{-}\right)\right.$on the other hand act as reducers when interacting with $\mathrm{O}_{2}$ as shown in Equation 10. A chain termination occurs resulting in the destruction of the dye radicals as shown in Equations 11, 12 and 13. Finally, the interaction between the positive valance band holes $\left(\mathrm{TiO}_{2}\left(\mathrm{~h}_{\mathrm{VB}}^{+}\right)\right.$and the conduction band electrons $\left(\mathrm{TiO}_{2}\left(\mathrm{e}_{\mathrm{CB}}^{-}\right)\right.$results in the production of heat as shown in Equation 14.

In this study, maximum degradations of $46.7 \%$ and $2.84 \%$ were observed when the alkaline $(\mathrm{pH}=10.5)$ least concentrated $(50 \mathrm{mg} / \mathrm{L})$ and the most concentrated $(500 \mathrm{mg} / \mathrm{L})$ dye solutions were treated with $\mathrm{UV} / \mathrm{TiO}_{2}$ using the longest retention time of $60 \mathrm{~min}$, respectively. These were about $72.23 \%$ and $76.06 \%$ increases in the removal efficiency above those obtained with the treatments with UV alone for the 50 and $500 \mathrm{mg} / \mathrm{L}$ dye concentrations, respectively. However, the maximum degradation observed for the least concentrated (50 $\mathrm{mg} / \mathrm{L})$ and the most concentrated $(500 \mathrm{mg} / \mathrm{L})$ dye solutions when the shortest retention time of $5.2 \mathrm{~min}$ was used were $1.64 \%$ and $0 \%$, respectively. This was about $96.96 \%$ increase for the alkaline $(\mathrm{pH}=10.5)$ least concentrated $(50 \mathrm{mg} / \mathrm{L})$ dye solution above that obtained with the treatment of UV alone.

Kusvuran et al. (2004) reported $40 \%$ degradation of $40 \mathrm{mg} / \mathrm{L}$ reactive red 120 dye when the dye solution was exposed to $\mathrm{UV} / \mathrm{TiO}_{2}$ for $30 \mathrm{~min}$. Kavitha and Palanisamy (2010) stated that only a slight degradation was observed when azo dyes were exposed to $\mathrm{UV} / \mathrm{TiO}_{2}$ for $30 \mathrm{~min}$ and that could be due to the absorption of dye molecules onto the surface of $\mathrm{TiO}_{2}$. The authors also noted a degradation of $84 \%$ when the dye solution was exposed for $120 \mathrm{~min}$. Verma and Ghaly (2008) reported $12.5 \%$ degradation of $300 \mathrm{mg} / \mathrm{L}$ remazol dye after exposing the dye solution to $\mathrm{UV} / \mathrm{TiO}_{2}$ for $84 \mathrm{~min}$ and a higher degradation of $46.70 \%$ for low dye concentration $(50 \mathrm{mg} / \mathrm{L})$ after exposure for $60 \mathrm{~min}$. Sohrabi and Ghavami (2008) noted $83.58 \%$ degradation when the dye solution was exposed to $\mathrm{UV} / \mathrm{TiO}_{2}$ for 140 min. The removal efficiency obtained in this study is higher than those reported in literature for similar concentrations and retention times.

\subsection{Effect of Temperature}

The current study was carried out at ambient temperature $\left(25^{\circ} \mathrm{C}\right)$. Muruganandham and Swaminathan (2004) stated that low pressure UV lamps were found to 
emit low energy and the rise in the temperature of the dye solution had no effect on the removal efficiency of reactive orange 4 dye. Mahmoud et al. (2007) treated a remazol dye solution in UV reactor at 25 and $100^{\circ} \mathrm{C}$ and obtained a maximum degradation of $12.3 \%$ under both temperatures and indicated that the temperature had no effect on degradation of dye. Galindo and Kalt (1999) stated that there was no significant change in the degradation rate when dye solutions containing acid orange 5, 6, 7, 20 and 52 were treated with UV alone in the temperature range of $22-45^{\circ} \mathrm{C}$. Muruganandham and Swaminathan (2004) stated that when textile dyes of various concentrations $(78-390 \mathrm{mg} / \mathrm{L})$ were exposed to low pressure UV lamps, the photons produced were not able to penetrate the organics and as a result the production of hydroxyl radicals $\left(\mathrm{OH}^{\circ}\right)$ are decreased (Equations 2-5). The authors suggested the use of additional oxidants for effective dye removal efficiency.

However, reports in the literature indicated the influence of temperature on the dye degradation when UV is combined with other oxidants. Jain and Sikarwar (2008) noted that degradation of erioglaucine dye as a result of exposure to $\mathrm{UV} / \mathrm{TiO}_{2}$ increased as the temperature was increased from 20 to $40^{\circ} \mathrm{C}$. Saien and Soleymani (2007) reported $7 \%$ increase in dye degradation as the temperature was increased from $15{ }^{\circ} \mathrm{C}$ to $45^{\circ} \mathrm{C}$. Stasinakis (2008) reported that the dye degradation rate as a result of exposure to $\mathrm{UV} / \mathrm{TiO}_{2}$ was found to decrease when the temperature of the dye solution was increased from 25 to $80^{\circ} \mathrm{C}$. Saien and Soleymani (2007) and Jain and Sikarwar (2008) stated that higher temperatures lead to the recombination of the positive $\left(\mathrm{TiO}_{2} \quad \mathrm{~h}_{\mathrm{VB}}^{+}\right)$valance-band holes (which interacts with $\mathrm{H}_{2} \mathrm{O}$ to produce $\mathrm{OH}^{\circ}$ radicals) and the negative $\left(\mathrm{TiO}_{2}\left(\mathrm{e}_{\mathrm{CB}}^{-}\right)\right.$conduction-band electrons (which interact with $\mathrm{OH}^{-}$to produce $\mathrm{OH}^{\circ}$ radicals) as shown in Equations 8 and 9 and as a result the concentration of hydroxide radicals $\left(\mathrm{OH}^{\circ}\right)$ was significantly reduced. They also noted that the increase in temperature decreases the solubility of oxygen in water with the consequent reduction in the production of radicals $\left(\mathrm{O}^{\circ}\right.$, $\mathrm{O}_{3}{ }^{\circ}$ and $\mathrm{H}_{2} \mathrm{O}_{2}$ ) by UV (Equations 2-4). They concluded that a temperature higher than $45^{\circ} \mathrm{C}$ should not be used as it will result in low degradation efficiency.

\subsection{Effect of $\mathrm{pH}$}

In this study the first two sets of experiments (UV and $\mathrm{UV} / \mathrm{TiO}_{2}$ ) were carried out after adjusting the $\mathrm{pH}$ of the dye solution to 10.5 which is within the range of $\mathrm{pH}$ of the textile effluent (10-11). In the third set of experiments, the most concentrated $(500 \mathrm{mg} / \mathrm{L})$ and the least concentrated $(50 \mathrm{mg} / \mathrm{L})$ dye solutions were treated with $\mathrm{UV} / \mathrm{TiO}_{2}$ under acidic condition $(\mathrm{pH}=3)$. Adjusting the $\mathrm{pH}$ of the dye solution to 3 increased the degradation efficiency from $46.70 \%$ (at $\mathrm{pH} 10.5$ ) to $86.45 \%$ (39.75\% increase) for the least concentrated $(50 \mathrm{mg} / \mathrm{L})$ dye solution and from $2.84 \%$ (at $\mathrm{pH} 10.5$ ) to $14.94 \%$ (12.1\% increase) for the most concentrated $(500 \mathrm{mg} / \mathrm{L})$ dye solution after treatment with $\mathrm{UV} / \mathrm{TiO}_{2}$ for $60 \mathrm{~min}$.

Verma and Ghaly (2008) reported no significant degradation of $50 \mathrm{mg} / \mathrm{L}$ remazol brilliant blue dye when the solution was treated with UV alone at a $\mathrm{pH}$ of 7 and a temperature of $25^{\circ} \mathrm{C}$ whereas $27.01 \%$ degradation of the dye was achieved after $60 \mathrm{~min}$ exposure to UV alone at $25^{\circ} \mathrm{C}$ after the $\mathrm{pH}$ was adjusted to 10.5 . Sugiarto et al. (2002) reported to have found no significant degradation of the rhodamine B, methyl orange and chicago sky blue dyes when exposed to UV alone after adjusting the $\mathrm{pH}$ to 3.5. Malik and Sanyal (2004) noted that the degradation rates of the dye when using UV even under a lower $\mathrm{pH}$ was much slower when compared to using UV in a combination with other oxidants.

Several researches reported that the effect of $\mathrm{pH}$ on the degradation efficiency of textile dyes as a result of exposure to $\mathrm{UV} / \mathrm{TiO}_{2}$ was significant. Kavitha and Palanisamy (2011) stated that the photocatalytic activity was maximum under acidic condition and was found to decrease when the $\mathrm{pH}$ was increased above 6 . Kusvuran et al. (2004) reported 90\% degradation of $40 \mathrm{mg} / \mathrm{L}$ reactive red 120 dye as a result of exposure to $\mathrm{UV} / \mathrm{TiO}_{2}$ when the $\mathrm{pH}$ was adjusted to 3 and found the degradation efficiency to decrease with increase in $\mathrm{pH}$. Neamtu et al. (2003) examined colour removal at different $\mathrm{pH}$ levels $(2,3,6.5$ and 9.7) and found the best colour removal efficiency (99\%) of reactive red 120 to be achieved at $\mathrm{pH}$ of 2 within $15 \mathrm{~min}$. Kusvuran et al. (2004) and Saien and Soleymani (2007) stated that textile dyes have sulfonated groups in their structures which are negatively charged. The acidic medium influences the absorption of dye onto the $\mathrm{TiO}_{2}$ surface and the $\mathrm{OH}^{\circ}$ radicals created aids in the destruction of dye. On the other hand, the alkaline medium does not enhance the absorption of dye onto the surface of $\mathrm{TiO}_{2}$ resulting in a low degradation efficiency.

In the present study, the increases in degradation efficiency as a result of adjusting the $\mathrm{pH}$ to 3 do not justify the cost of chemicals added to adjust the $\mathrm{pH}$ of the dye effluent from 10 to 3 before treatment and then from 3 to 7 before the final discharge.

\subsection{COD Removal}

In this study, the acidic $(\mathrm{pH}=3)$ least concentrated $(50 \mathrm{mg} / \mathrm{L})$ and most concentrated $(500 \mathrm{mg} / \mathrm{L})$ dye solutions were treated with $\mathrm{UV} / \mathrm{TiO}_{2}$. A COD reduction of $83.43 \%$ was observed for the acidic $(\mathrm{pH}=3)$ least 
concentrated dye solution $(50 \mathrm{mg} / \mathrm{L})$ compared to a COD reduction of $41.88 \%$ at the alkaline $\mathrm{pH}$ of 10.5 . Also, a COD reduction of $20.82 \%$ was observed for the acidic $(\mathrm{pH}=3)$ most concentrated dye solution $(500 \mathrm{mg} / \mathrm{L})$ compared to a COD reduction of $7.67 \%$ at the alkaline $\mathrm{pH}$ of 10.5 .

Liu et al. (2006) achieved a COD removal efficiency of $73.01 \%$ (31.5 to $8.5 \mathrm{mg} / \mathrm{L})$ when an acid yellow 17 was exposed to $\mathrm{UV} / \mathrm{TiO}_{2}$ for 9 hours at $\mathrm{pH} 3$. Park et al. (2003) reported a COD removal efficiency of 56\% (96 to $42.24 \mathrm{mg} / \mathrm{L})$ when a reactive red 120 dye was exposed to $\mathrm{UV} / \mathrm{TiO}_{2}$ for $90 \mathrm{~min}$ at $\mathrm{pH}$ 5. Sahunin et al. (2006) achieved a COD removal efficiency of $52 \%(27,000$ to $14040 \mathrm{mg} / \mathrm{L}$ ) when a textile effluent (containing acid dye and various chemicals) was treated with $\mathrm{UV} / \mathrm{TiO}_{2} / \mathrm{Fe}^{2+}$ for $5 \mathrm{~min}$ at $\mathrm{pH} 3$. The COD results obtained in the present study showed much higher COD reductions in much shorter retention times.

Photooxidation treatments of textile effluents at acidic $\mathrm{pH}$ have proven to be more effective in the degradation of textile dyes than at alkaline $\mathrm{pH}$. However, in the present study, when effluents with an initial $\mathrm{pH}$ of 10.5 were treated with $\mathrm{UV} / \mathrm{TiO}_{2}$, the $\mathrm{pH}$ was found to decrease to a $\mathrm{pH}$ of 9.7 after $60 \mathrm{~min}$, making the $\mathrm{pH}$ of the effluent near the permitted discharge limit of 6-9. Also, exposure of acidic $(\mathrm{pH}=3)$ dye solution to $\mathrm{UV}$ for $60 \mathrm{~min}$ was found to decrease the $\mathrm{pH}$ further to 2.4 thus making it more acidic. Although treatment with acidic $\mathrm{pH}$ was proven to be faster, the cost of chemicals to be added to the effluent to bring the $\mathrm{pH}$ to 3 before treatment and then to bring it to neutral $(\mathrm{pH}=7)$ before the final disposal does not justify the treatment cost.

\section{CONCLUSION}

The effectiveness of Advanced Oxidation Process (AOP) against the degradation of ten different reactive red 120 dye concentrations were tested using UV and $\mathrm{TiO}_{2}$ at various retention times. When the alkaline $(\mathrm{pH}=$ 10.5 ) reactive red 120 dye solutions were treated using a low pressure (380 nm intensity) UV lamp, a maximum degradation efficiency of $27.01 \%$ was obtained for the least concentrated dye $(50 \mathrm{mg} / \mathrm{L})$ solution and only a degradation efficiency of $0.33 \%$ was obtained for the most concentrated $(500 \mathrm{mg} / \mathrm{L})$ dye solution. When the alkaline $(\mathrm{pH}=10.5)$ reactive red 120 solutions were exposed to a combination of $\mathrm{UV} / \mathrm{TiO}_{2}$, a maximum degradation efficiency of $46.70 \%$ was obtained for the lease concentrated $(50 \mathrm{mg} / \mathrm{L})$ dye solution after $60 \mathrm{~min}$ and only a degradation efficiency of $2.84 \%$ was obtained for the most concentrated $(500 \mathrm{mg} / \mathrm{L})$ dye solution after 60 min. When the $\mathrm{pH}$ of the reactive red 120 dye solution was reduced to 3 , a degradation efficiency of $56.45 \%$ was obtained for the least concentrated (50 $\mathrm{mg} / \mathrm{L})$ dye solution at $60 \mathrm{~min}$ and a degradation efficiency of $14.94 \%$ was obtained for the most concentrated $(500 \mathrm{mg} / \mathrm{L})$ dye solution at $60 \mathrm{~min}$. However, the increase in degradation efficiency obtained in this study does not justify the cost of chemicals added to adjust the $\mathrm{pH}$ to 3 before treatment and then to 7 before final disposal. Also, the addition of chemicals (to adjust the $\mathrm{pH}$ ) increase the COD of the dye solution, thereby necessitating a further costly treatment.

\section{ACKNOWLEDGEMENT}

This research project was supported by the Natural Science and Engineer Research Council (NSERC of Canada).

\section{REFERENCES}

Alfons, V. and K. Soo-Myung, 2003. Advanced Oxidation Processes (AOPs) in wastewater treatment. Ind. Eng. Chem., 10: 33-40.

Azbar, N., T. Yonar and K. Kestioqlu, 2004. Comparison of various advanced oxidation processes and chemical treatment methods for COD and colour removal from a polyester and acetate fibre dyeing effluent. Chemosphere, 55: 35-43. DOI: 10.1016/j.chemosphere.2003.10.046

Babu, R., A. Parande, S. Raghu and T. Kumar, 2007. Textile technology-cotton textile processing: Waste generation and effluent treatment. J. Cotton Sci., 11: 141-153.

Chen, J., Q. Wang, Z. Hua and G. Du, 2007. Research and application of biotechnology in textile industries in China. Enzyme Microbial. Tech., 40: 1651-1655. DOI: $10.1016 /$ j.enzmictec.2006.07.040

Das, S., 2000. Textile effluent treatment-A Solution to the Environmental Pollution.

Dyes and Pigments, 2010. Textile Dyes.

EPA, 2003. Wastewater Technology Fact Sheet: Screening and Grit Removal.

EPA US, 2012. Environmental Protection Agency United States, Ozone.

Eswaramoorthi, S., K. Dhanapal and D. Chauhan, 2008. Advanced in textile waste water treatment: The case for UV-Ozonation and membrane bioreactor for common effluent treatment plants in tirupur. Tamil Nadu, India. Environment with People's Involvement $\&$ Co-ordination in India. Coimbatore, India.

Galindo, C. and A. Kalt, 1999. UV- $\mathrm{H}_{2} \mathrm{O}_{2}$ oxidation of monoazo dyes in aqueous media: A kinetic study. Dyes Pigments, 40: 27-35. DOI: 10.1016/S0143-7208(98)00027-8

Georgiou, D., P. Melidis, A. Aivasidis and K. Gimouhopouls, 2002. Degradation of azo-reactive dyes by ultraviolet radiation in the presence of hydrogen peroxide. Dyes Pigments, 52: 69-78. DOI: $10.1016 / \mathrm{S} 0143-7208(01) 00078-\mathrm{X}$ 
Ghoreishi, S. and R. Haghighi, 2003. Chemical catalytic reaction and biological oxidation for treatment of non-biodegradable textile effluent. Chemical Eng. J., 95: 163-169. DOI: 10.1016/S1385-8947(03)00100-1

Gogate, P. and A. Pandit, 2004. A review of imperative technologies for wastewater treatment I: Oxidation technologies at ambient conditions. Adv. Environ, 8: 501-551. DOI: 10.1016/S1093-0191(03)00032-7

Ince, N. and D. Gonenc, 1997. Treatability of a textile azo dye by $\mathrm{UV} / \mathrm{H}_{2} \mathrm{O}_{2}$. Envir. Tech., 18: 179-185.

Jain, R. and S. Sikarwar, 2008. Photodestruction and COD removal of toxic dye erioglaucine by $\mathrm{TiO}_{2}-\mathrm{UV}$ Process: Influence of operational parameters. Phys. Sci., 3: 299-305.

Jain, R., M. Bhargava and N. Sharma, 2003. Electrochemical studies on a pharmaceutical azo dye: Tetrazine. Ind. Eng. Chem. Res., 42: 243-247. DOI: $10.1021 / \mathrm{ie} 020228 \mathrm{q}$

Kant, R., 2012. Textile dyeing industry an environmental hazard. Univ. Inst. Fashion Tech. Punjab Univ. Chandigar, India, 4: 22-26.

Kavitha, S. and P. Palanisamy, 2010. Photocatalytic degradation of vat yellow 4 using $\mathrm{UV} / \mathrm{TiO}_{2}$. Morden Applied Sci., 4: 130-142.

Kdasi, A., A. Idris, K. Saed and C. Guan, 2004. Treatment of textile wastewater by advanced oxidation processes-a review. Global Nest. Int. J., 6: 222-230

Keane, J. and D. Velde, 2008. The role of textile and clothing industried in growth and development strategies. investment and growth programme. Overseas Development Institute.

Kesselman, J., O. Weres, N. Lewis and M. Hoffmann, 1996. Electrochemical production of hydroxyl radical at polycrystalline nb-doped $\mathrm{TiO}_{2}$ electrodes and estimation of the partitioning between hydroxyl radical and direct hole oxidation pathways. J. Phys. Chem. B, 101: 2637-2643. DOI: 10.1021/jp962669r

Kusvuran, E., O. Gulnaz, S. Irmak, O. Atanur, Yavuz and I.O. Erbatur, 2004. Comparison of several advanced oxidation processes for the decolorization of reactive red 120 azo dye in aqueous solution. J. Hazardous Materials, 109: 85-93. DOI: 10.1016/j.jhazmat.2004.03.009

Lafond, R., 2008. Moving Bed Biofilm Reactor (MBBR) A Compact Technology for Upgrading Canadian Municipal Aerated Lagoons. VP Business Development and Marketing.

Liu, C., Y. Hsieh, P. Lai, C. Li and C. Kao, 2006. Photodegradation treatment of azo dye wastewater by $\mathrm{UV} / \mathrm{TiO}_{2}$ process. Dyes Pigments, 68: 191-195. DOI: 10.1016/j.dyepig.2004.12.002
Mahmoud, A., M. Brooks and E. Ghaly, 2007. Decolourization of remazol brilliant blue dye effluent by advanced photo oxidation process $\left(\mathrm{H}_{2} \mathrm{O}_{2} / \mathrm{UV}\right.$ System). Am. J. Applied Sci., 4: 1054-1062. DOI: 10.3844/ajassp.2007.1054.1062

Malik, P. and S. Sanyal, 2004. Kinetics of discolourisation of azo dyes in wastewater by $\mathrm{UV} / \mathrm{H}_{2} \mathrm{O}_{2}$ Proc. Purif Tech., 36: 167-175.

Meric, S., D. Kaptan and T. Olmez, 2004. Color and COD removal from wastewater containing rective black 5 using fenton's oxidation process. Chemosphere, 54: 435-441. DOI: 10.1016/j.chemosphere.2003.08.010

Muruganandham, M. and M. Swaminathan, 2004. Photochemical oxidation of reactive azo dye with UV $-\mathrm{H}_{2} \mathrm{O}_{2}$ Process. Dyes Pigments, 62: 269-275. DOI: 10.1016/j.dyepig.2003.12.006

Neamtu, M., A. Yediler, I. Siminiceanu and A. Kettrup, 2003. Oxidation of commercial reactive azo dye aqueous solutions by the photo-fenton and fenton-like processes. J. Photochem. Photobiol. A: Chem., 161: 87-93. DOI: 10.1016/S1010-6030(03)00270-3

Nese, T., N. Sivri and I. Toroz, 2007. Pollutants of textile industry wastewater and assessment of its discharge limits by water quality standards. Turkish J., 7: 97-103.

Ntuli, F., I. Omoregbe, P. Kuipa, E. Muzenda and M. Belaid, 2009. Characterization of effluent from textile wet finishing operations. WCECS, 1: 20-22.

Ozkan, A., M. Ozkan, R. Gurkan, M. Akcay and M. Sokmen, 2004. Photocatalytic degradation of a textile azo dye, Sirius Gelb GC on $\mathrm{TiO}_{2}$ particles in the absence and presence of UV irradiation: The Effects of some inorganic anions on the photocatalysis. Photochemi. Photobiol. A: Chem., 163: 29-35. DOI: 10.1016/S1010-6030(03)00426-X

Park, J., E. Choi and K. Gil, 2003. Removal of reactive DYE using $\mathrm{UV} / \mathrm{TiO}_{2}$ in circular type reactor. J. Environ. Sci. Health, 38: 1389-1399. DOI: 10.1081/ESE-120021133

Sahunin, C., J. Kaewboran and M. Hunsom, 2006. Treatment of textile dyeing watewater by photo oxidation using UV/ $\mathrm{H}_{2} \mathrm{O}_{2} / \mathrm{Fe}^{2+}$ reagents. Dept. Chem Tech, Faculty of Science, Chulalongkorn University, Bankok, Thailand.

Saien, J. and A. Soleymani, 2007. Degradation and mineralization of direct blue 71 in a circulating upflow reactor by $\mathrm{UV} / \mathrm{TiO}_{2}$ process and employing a new method in kinetic study. Hazardous Materials 144: 506-512. DOI: 10.1016/j.jhazmat.2006.10.065

SET, 2012. UV Ozone Advanced Oxidation Process. 
Sohrabi, M. and M. Ghavami, 2008. Photocatalytic degradation of direct red 23 dye using $\mathrm{UV} / \mathrm{TiO}_{2}$ : Effect of operational parameters. J. Hazardous Matrials, 153: 1235-1239. DOI: 10.1016/j.jhazmat.2007.09.114

Stasinakis, A., 2008. Use if Selected Advances Oxidation Processes (Aops) for wastewater treatment -a mini review. Global NEST,10: 376-385.

Sugiarto, A., I. Shunsuke, T. Ohshima, M. Sato and J. Skalny, 2002. Oxidative decolouration of dyes by pulsed discharge plasma in water. J. Electrostatic, 58: 135-145. DOI: 10.1016/S0304-3886(02)00203-6

Tang, W. and H. An, 1995. UV/TiO 2 photocatalytic oxidation of commercial dyes in aqueous solutions. Chemosphere, 31: 4157-4170. DOI: 10.1016/0045-6535(95)80015-D
Tang, W., Z. Zhang, H. An, M. Quintana and D. Torres, 2010. $\mathrm{TiO}_{2} / \mathrm{UV}$ photodegradation of azo dyes in aqueous solutions. Environ. Technol., 18: 1-12.

Tilley, E., B. Etter, R. Khadka and K. Udert, 2008. Compendium of sanitation systems and technologies. Water Res., 45: 852-862.

Verma, M. and A. Ghaly, 2008. Treatment of remazol brilliant blue dye effluents by advanced photo oxidation process in $\mathrm{TiO}_{2} / \mathrm{UV}$ and $\mathrm{H}_{2} \mathrm{O}_{2} / \mathrm{UV}$ reactors. Am. J. Eng. Applied Sci., 1: 230-240. DOI: 10.3844/ajeassp.2008.230.240

Vinitnantharat, S., W. Chartthe and A. Pinitwakul, 2003. Toxicity of reactive red 141 and basic 14 to algae and waterflea. Division Environ. Technol., 58: 1193-1198. DOI: 10.2166/wst.2008.476 